\title{
AN INTENSIVE REVIEW ON HEALTH AND SAFELY FACTORS AFFECTING CONSTRUCTION PROJECTS' PRODUCTIVITY
}

\author{
Karim M. El-Dash ${ }^{1}$, Mohamed Shawky Abdel Monem², Rasha Laith Mohammed Salih ${ }^{3}$ \\ 1,2 Faculty of Engineering at Shoubra, Benha University,3 Ministry of Electricity, Iraq
}

Received :1 Sept. $2021 \quad$ Accepted:11 Oct. 2021

\begin{abstract}
Construction projects have the highest level of occupational safety and health. This research is highlighted the relationship between productivity, health, and safety to increase company awareness regarding the importance of health and safety to improve construction productivity. To determine the most prevalent factors influencing workers' health, performance, and productivity, a comprehensive literature study is conducted. Consequently, 36 factors were discovered and categorized into five groups: project management-related factors, contractor-related factors, supervision- related factors, safety- related factors, and environment-related factors. According to the preliminary findings of this study, interventions will assist businesses in achieving their objectives and improving their performance. Improving working conditions and implementing health and safety management programs will increase productivity by creating better working conditions.

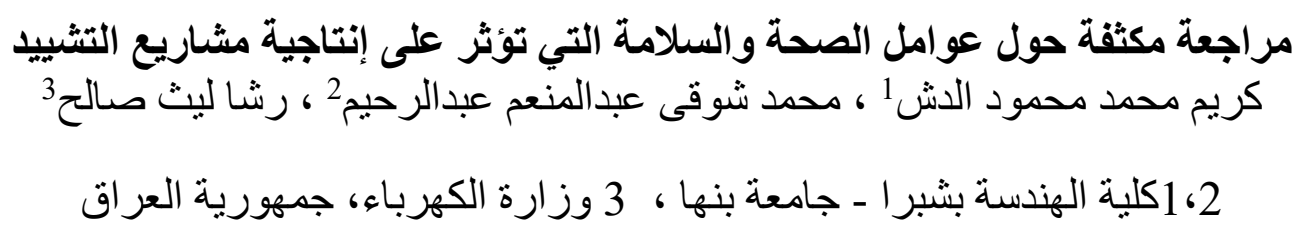

\footnotetext{
ملخص البحث

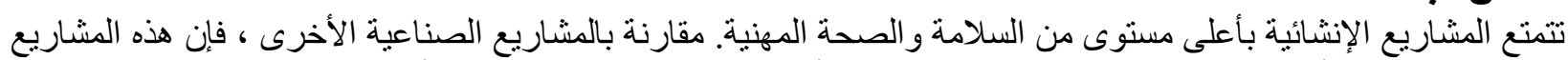

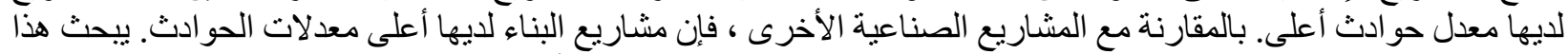

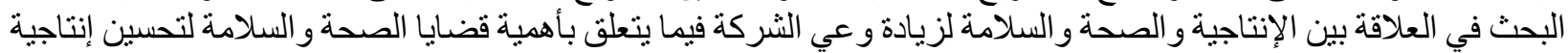

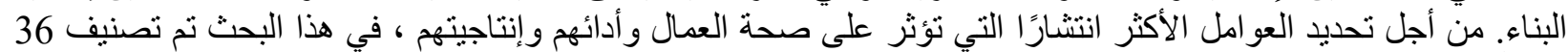

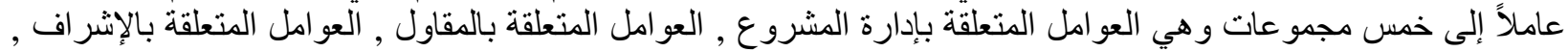

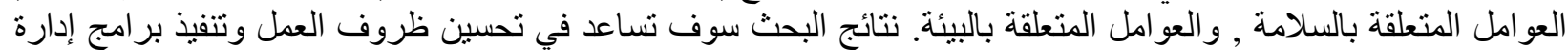

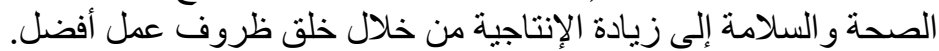




\section{Introduction}

Construction projects are facing several issues and problems. Due to inadequate management and a lack of sufficient performance measurements, it is difficult to find construction projects that are completed on time, on budget, and to the required quality [1].

Continuous monitoring of risky conditions and action is required for construction safety and health in order to eliminate potential dangers as soon as possible computer vision techniques have been used to extract safety-related information from site photographs and videos as a robust and automated way of field observation, and are viewed as effective alternatives to present timeconsuming and unreliable manual observational practices [2]. Contractors, subcontractors, owners, consultants, and all other project stakeholders are encouraged to analyze all productivityinfluencing elements in their control to avoid undesirable consequences [3]. The most significant factors that influence labor productivity: poor labor supervision, payment delays, poor work environment, lack of skilled workers, and bad weather conditions [4].

The organization's safety and health management system should be reviewed and improved regularly to improve its overall safety and health performance [5]. However, information on using personal protection equipment (PPE) such as hand gloves, hardhats, overalls, safety boots, earplugs, safety harnesses with lanyards, and face shields by construction workers is rare. In Kampala, Uganda, this study is investigated the use of personal protective equipment (PPE) and its determinants among building construction workers [6]. Workers face various issues, including unpaid on time for completed work, living in deplorable conditions, being responsible for their healthcare, and being unable to prepare for the future. The majority of contractors blame workers for any project failure, claiming that they are untrained [7]

\section{Previous studies}

Health and safety in the construction sector are critical issues causing high accident rate in the construction industry. Implementing the building information modeling (BIM) methodology has been proved in recent research to be beneficial can make construction sites and building maintenance more pleasant places to work [8]. Construction projects in both developed and developing countries have been evaluated for their safety performance. In fact, the construction industry makes a significant contribution to both economic and social elements. It is, however, considered the most dangerous industry in terms of personal safety and health. A variety of circumstances causes accidents at construction sites are caused by number of factors, including safety management errors and poor maintenance. Training programs, the human aspect, an act of God, an out-of-date method, and a lack of a defined monitoring strategy are all factors to consider [9]. A construction project's time, cost, and quality are all affected by worker skills. The construction industry's fierce competition encourages companies to improve their labours skills to stay competitive. The skilled labor is mandatory and considered as the primary sources for the construction industry. A skilled worker must have professional training, at least two years of experience, and be familiar with construction materials, equipment, and methods safety and physical conditioning [10]. For a long time, the construction industry is blamed for having unacceptably high injury and fatality rates. Small construction companies have a greater injury rate than large construction companies, according to previous study. Despite the fact that the industry is dominated by a large number of small businesses, little is known about their occupational health and safety (OHS) requirements, practices, or limits [11]. Construction site health and safety is concerned with the psychological and physical well-being of construction employees as well as those people whose health is affected by construction activities. Employers, employees, governments, and project stakeholders are all concerned. As a result, health and safety is a financial and humanitarian responsibility that requires proper management supervision [12]. 
Some health risks have long-term consequences, while others have immediate consequences. The most commonly reported chronic health danger is "workers falling from height" and "electric shocks," while the most commonly reported acute health hazard is "Exposure to hazardous substances" is a term used to describe the act of being exposed to Poor safety practices in construction sites have been linked to a lack of awareness about site safety and a dislike of wearing Personal Protective Equipment (PPE) [13]. Identifying and evaluating factors that affect worker productivity becomes a critical issue for industrial practitioners in this regard. Many researches in the academic literature have looked into these aspects and their connections to worker productivity [14]. Because construction sites are subjected to a significant risk of harm, occupational safety is a critical component of production efficiency in this industry. The injured workers missed workdays and were unable to earn a living. Financial costs have an impact on the construction industry's social and economic efficiency [15]. It has been determined that management factors such as insufficient incentives; material factors such as poor material quality; labor factors such as inadequate quality and training of labors; supervision factors such as site supervisor incompetence; and equipment factors such as frequent equipment damage are all identified.

\section{Research methodology}

The research methodology is designed to involve four main steps to achieve the research objectives. First, the literature review is analyzed to determine the problems of the workplace environment and their effect on workers' health, performance, and productivity. Second, it will identify the factors affecting workers' health, performance, and productivity. Also, develop a questionnaire to assess the workplace environment's effect on workers' health, performance, and productivity. Third, gather information from construction professionals. Last step is to analyze the information and calculate the total importance index for each factor.

A total of 36 factors are classified into five categories: 1- project management, 2- contractor, 3supervision, 4- safety 5-environment.

As a result, the initial questionnaire is created in two sections. The proposed questionnaire's first section contains demographic information about the respondents, while the second section focuses on the factors that influence workers' health, performance, and productivity. Respondents are asked four questions for each factor. The first question concerned the frequency at which this factor occurred, and the second concerned the severity with which this factor impacted workers' health. The third question is about the impact severity on the performance of workers. The fourth question is the impact severity on the productivity of workers.

A five-point scale is used to rate the four questions, ranged from 1- exceptionally low 2- low 3moderate 4- high 5- very high. At the end of the questionnaire the respondents can select a set of alternatives.

\section{Categorization of factors affecting workers' health, performance, and productivity}

Factors are classified into five common related groups, which are, 1) project management- related factors, 2) contractor- related factors, 3) supervision- related factors, 4) safety- related factors, 5) environment- related factors.

These factors are discussed according to each related group in the following section, as described below.

\subsection{Project Management- Related Factors}




\section{AN INTENSIVE REVIEW ON HEALTH AND SAFELY FACTORS AFFECTING CONSTRUCTION PROJECTS' PRODUCTIVITY}

Project management is the tool that can be used to increase the success of projects and, as a result, the success of construction companies. As a result, it's important looking into the factors that can help you improve your project management [17]. In construction, project managers are in charge of ensuring that the owner's physical development is completed within the restrictions of cost, schedule, quality, and safety [18]. Also, the construction industry is confronted with productivity issues, which are mainly associated with labor performance. Labor performance is influenced by a variety of factors and is usually related to time, cost, and quality [19]. Table 2 shows the five most common factors related to Project Management, which have been identified from excessive previous studies.

Table 1: The factors that impact labor productivity and reference in the construction industry

\begin{tabular}{|c|c|c|}
\hline Categories & $\begin{array}{c}\text { The factors that impact labor } \\
\text { productivity }\end{array}$ & References \\
\hline Manpower & $\begin{array}{l}\text { Inexperience in the workplace, } \\
\text { Labour unfaithfulness, } \\
\text { Misunderstandings among labor, } \\
\text { Lack of competition, and } \\
\text { Labour personal problems. }\end{array}$ & [20], [21] \\
\hline Leadership & $\begin{array}{l}\text { Misunderstandings between labour/ } \\
\text { superintendents, } \\
\text { Lack of periodic meetings with } \\
\text { labour, and } \\
\text { Method of employment (using direct } \\
\text { work system). }\end{array}$ & [23], [22] \\
\hline Motivation & $\begin{array}{l}\text { Payment delay, } \\
\text { Lack of financial motivation systems, } \\
\text { Lack of places for eating and } \\
\text { relaxation, and } \\
\text { Lack of training sessions }\end{array}$ & {$[25],[24]$} \\
\hline Time & $\begin{array}{l}\text { Misuse of time schedule, } \\
\text { Work overtime, and } \\
\text { Increase number of labour in order to } \\
\text { accelerate work and working } 7 \text { days } \\
\text { per week without taking any holidays. }\end{array}$ & {$[19],[26]$} \\
\hline Tools/ Materials & $\begin{array}{l}\text { Materials, Tool, and equipment } \\
\text { shortages, and } \\
\text { Unsuitability of materials storage } \\
\text { location. }\end{array}$ & {$[28][27]$} \\
\hline Supervision & $\begin{array}{l}\text { Supervisors' absenteeism } \\
\text { Lack of labour supervision }\end{array}$ & {$[30],[29]$} \\
\hline Project & $\begin{array}{l}\text { Rework / Repairs } \\
\text { Drawings and specifications } \\
\text { alteration during execution. }\end{array}$ & [1],[29] \\
\hline Safety & $\begin{array}{l}\text { Accidents } \\
\text { Violation of safety precautions. }\end{array}$ & [32], [31] \\
\hline Quality & $\begin{array}{l}\text { Low quality of raw materials } \\
\text { High quality of required work }\end{array}$ & [34], [33] \\
\hline External factors & $\begin{array}{l}\text { Weather changes } \\
\text { Insufficient lighting }\end{array}$ & {$[36],[35]$} \\
\hline
\end{tabular}


Table 2: Factors related to Project Management group

\begin{tabular}{|l|l|c|}
\hline NO & \multicolumn{1}{|c|}{ Factors } & Sources \\
\hline $\mathbf{1}$ & Low premiums for workers' insurance. & {$[37]$} \\
\hline $\mathbf{2}$ & $\begin{array}{l}\text { Lack of incentives to motivate workers' } \\
\text { performance and productivity. }\end{array}$ & {$[38]$} \\
\hline $\mathbf{3}$ & $\begin{array}{l}\text { The existence of the Social Care Law, which } \\
\text { protects workers and their families and provides a } \\
\text { pension. }\end{array}$ & {$[39]$} \\
\hline $\mathbf{4}$ & $\begin{array}{l}\text { Workers' negative attitude at workplace due to } \\
\text { interpersonal relations, job assignment, and } \\
\text { overtime duty. }\end{array}$ & {$[40]$} \\
\hline $\mathbf{5}$ & $\begin{array}{l}\text { Low workers' morale due to lack of clients' } \\
\text { satisfaction. }\end{array}$ & \\
\hline
\end{tabular}

\subsection{Contractor- Related Factors}

The Health and Safety Executive (HSE) considers it a priority to oversee the work of our contractors, suppliers, and partners, and it is an example of good practice. It must verify that the contractors, suppliers, and partners it employs are qualified to complete the work for which they have been appointed, while complying with health and safety requirements during the contract's duration [42]. Table 3 shows the nine most common factors related to contractor, which is identified from excessive previous studies.

Table 3: Factors related to contractor group

\begin{tabular}{|l|l|c|}
\hline $\mathbf{N O}$ & \multicolumn{1}{|c|}{ Factors } & Sources \\
\hline $\mathbf{6}$ & $\begin{array}{l}\text { Employment of young workers with no work } \\
\text { experience. }\end{array}$ & {$[43]$} \\
\hline $\mathbf{7}$ & $\begin{array}{l}\text { Absence of safety and security plan developed by the } \\
\text { construction contractor and approved by supervisor. }\end{array}$ & {$[44]$} \\
\hline $\mathbf{8}$ & $\begin{array}{l}\text { Starting work before site clearance from hazardous } \\
\text { objects and substances, such as mines, explosive } \\
\text { remnants of war, contaminated medical wastes. }\end{array}$ & {$[45]$} \\
\hline $\mathbf{9}$ & $\begin{array}{l}\text { Low quality of tools and lack of equipment manuals, } \\
\text { such as guides and checklists. }\end{array}$ & {$[46]$} \\
\hline $\mathbf{1 0}$ & $\begin{array}{l}\text { Debris removal by the construction contractor } \\
\text { outside site to places not authorized by the } \\
\text { municipality/local low. }\end{array}$ & $\begin{array}{l}\text { Unclean workplace due to absence of frequent debris } \\
\text { removal throughout the entire duration of work } \\
\text { execution. }\end{array}$ \\
\hline $\mathbf{1 2}$ & $\begin{array}{l}\text { Absence of site organization plan developed by the } \\
\text { construction contractor and approved by supervision } \\
\text { before starting the work to determine storage areas, } \\
\text { equipment yard, site office and temporary } \\
\text { workshops. }\end{array}$ & {$[47]$} \\
\hline $\mathbf{1 3}$ & $\begin{array}{l}\text { Partial or complete suspension of work due to } \\
\text { stoppage /repairing of machines. }\end{array}$ & {$[49]$} \\
\hline $\mathbf{1 4}$ & $\begin{array}{l}\text { Failure to report incidents immediately to the client } \\
\text { by the construction contractor and the site } \\
\text { supervision engineer. }\end{array}$ & {$[50]$} \\
\hline
\end{tabular}




\subsection{Supervision- Related Factors}

With the rapid development of the construction industry, the quantity and quality of government construction safety supervision personnel cannot keep up with the increasingly complex safety supervision scenario, resulting in safety oversight gaps [51]. Table 4 shows the six most common factors related to supervision, which is identified from excessive previous studies.

Table 4: Factors related to Supervision group

\begin{tabular}{|l|l|c|}
\hline $\mathbf{N O}$ & \multicolumn{1}{|c|}{ Factors } & Sources \\
\hline $\mathbf{1 5}$ & $\begin{array}{l}\text { Lack of training provided to workers on machinery } \\
\text { and equipment used at the workplace. }\end{array}$ & {$[52]$} \\
\hline $\mathbf{1 6}$ & $\begin{array}{l}\text { Lack of workers' skills, qualifications, experience } \\
\text { and capacity building. }\end{array}$ & {$[53]$} \\
\hline $\mathbf{1 7}$ & $\begin{array}{l}\text { Absence meeting of safety and security delivered by } \\
\text { a specialist to the workers to promote health } \\
\text { awareness and mitigation plans to reduce potential } \\
\text { risks. }\end{array}$ & {$[54]$} \\
\hline $\mathbf{1 8}$ & $\begin{array}{l}\text { Absence of/insufficient supervision provided by a } \\
\text { specialist in public safety and occupational health } \\
\text { for workers at the workplace. }\end{array}$ & {$[55]$} \\
\hline $\mathbf{1 9}$ & $\begin{array}{l}\text { Weak relationship between workers and supervisors } \\
\text { at the workplace. }\end{array}$ & {$[56]$} \\
\hline $\mathbf{2 0}$ & $\begin{array}{l}\text { Hitting a moving vehicle or stuck in moving parts or } \\
\text { machines. }\end{array}$ & \\
\hline
\end{tabular}

\subsection{Safety- Related Factors}

The construction industry is one of the most common industries where workers are injured and die, as this industry includes many dangerous works, including building skyscrapers, an offshore platform, and many others. From this standpoint, the Occupational Health and Safety management is the goal that must be cared for [57]. Table 5 shows the seven most common factors related to safety, which is identified from excessive previous studies.

Table 5: Factors related to Safety group

\begin{tabular}{|l|l|c|}
\hline NO & \multicolumn{1}{|c|}{ Factors } & Sources \\
\hline $\mathbf{2 1}$ & $\begin{array}{l}\text { Lack of personal protective equipment such as } \\
\text { helmets, belts, shoes, etc... }\end{array}$ & {$[58]$} \\
\hline $\mathbf{2 2}$ & $\begin{array}{l}\text { Discomfort at workplace and lack of essential } \\
\text { facilities required for workers. }\end{array}$ & {$[59]$} \\
\hline $\mathbf{2 3}$ & Absence of first-aid kits at the workplace. & {$[60]$} \\
\hline $\mathbf{2 4}$ & $\begin{array}{l}\text { Absence/invisibility of safety and security signs at } \\
\text { the workplace. }\end{array}$ & {$[61]$} \\
\hline $\mathbf{2 5}$ & Poor safety management. & {$[62]$} \\
\hline $\mathbf{2 6}$ & $\begin{array}{l}\text { Absence of integration of the Occupational Safety } \\
\text { and Health Administration into management system. }\end{array}$ & {$[63]$} \\
\hline $\mathbf{2 7}$ & Lack of emergency fire safety measures. & \\
\hline
\end{tabular}

\subsection{Environment- Related Factors}

The workplace environment impacts employee morale, productivity, and engagement - both positively and negatively. In most industries, the working environment is unsafe and unhealthy. 
Poorly constructed workstations, inadequate furniture, a lack of ventilation, insufficient lighting, excessive noise, insufficient fire safety measures, and a lack of personal protective equipment are just a few examples [40]. Table 6 shows the nine most common factors related to Environment, which have been identified from previous studies.

Table 6: Factors related to Environment group

\begin{tabular}{|c|c|c|}
\hline NO & Factors & Sources \\
\hline 28 & Exposure to heat (burns, sunstroke or fatigue). & [64] \\
\hline 29 & $\begin{array}{l}\text { Negative impact of environmental factors on } \\
\text { workplace, such as lack of natural lighting and } \\
\text { ventilation, high/low temperature, and extensive } \\
\text { noise. }\end{array}$ & [65] \\
\hline 30 & Exposure to noise (hearing problems). & [66] \\
\hline 31 & $\begin{array}{l}\text { Inhaling chemicals in the form of fumes, dust or } \\
\text { gases. }\end{array}$ & [67] \\
\hline 32 & $\begin{array}{l}\text { Frequent absence of workers due to exposure to } \\
\text { occupational accidents, such as falling from high } \\
\text { level or experiencing an electric shock and other } \\
\text { accidents. }\end{array}$ & [68] \\
\hline 33 & $\begin{array}{l}\text { Absence of sheds for temporary workshops at } \\
\text { workplace to protect the workers from direct sun and } \\
\text { rain such as: workshops of preparing steel } \\
\text { reinforcement bars, windows and air-ducts. }\end{array}$ & [69] \\
\hline 34 & $\begin{array}{l}\text { Exposure to radiation, ultraviolet radiation, arc } \\
\text { flashes, microwave waves or laser. }\end{array}$ & [70] \\
\hline 35 & $\begin{array}{l}\text { Allergies and dermatitis as a result of direct contact } \\
\text { of the skin with highly concentrated chemicals } \\
\text { substances. }\end{array}$ & [71] \\
\hline 36 & Violence at workplace. & [72] \\
\hline
\end{tabular}

\section{Conclusions}

This study's major aim was to determine the key elements that influence the health, performance, and productivity of construction workers. In conclusion, danger and risk are unavoidable in complicated construction projects, and they may continue to play havoc with workers indefinitely. A total of 36 factors were identified, and categorized into five groups: project management, contractor, supervision, safety, and the environment. We must thoroughly investigate all aspects that can result in hazards and increased risks in the construction site. It is clear that improving construction site safety performance is not easy, but it is possible. Workers must use their expertise, professional advice, and previous safety reports to design some regulations and training strategies for workers based on site-related hazards. Overall, improving safety performance and creating safer conditions in construction projects requires identifying hazards and types of risks that could negatively affect property and humans. Also, worker skill is directly proportional to labor productivity and, success of the construction projects. In addition, the research suggests some site management improvements to increase labor productivity and performance. The findings of this study suggest that, to improve labor productivity, the construction industry should implement labor productivity assessments such as material procurement schedules, safety programs, and incentive programs. System, as well as regular meetings with project managers to reduce the incidence of workplace accidents, special attention must be made to all stakeholders, starting with management, contractors, and the government, particularly in the construction industry. 


\section{References:}

[1] A. H. Mahmoud, "Factors affecting performance at the Iraqi Construction Projects, Ministry of Construction, and Housing and Municipalities and Public Works of Iraq as a case study," Asian J. Civ. Eng., vol. 21, no. 1, pp. 105-118, 2020, doi: 10.1007/s42107-019-00195-1.

[2] J. Seo, S. Han, S. Lee, and H. Kim, "Computer vision techniques for construction safety and health monitoring," Adv. Eng. Informatics, vol. 29, no. 2, pp. 239-251, 2015, doi: 10.1016/j.aei.2015.02.001.

[3] M. Gunduz and A. Abu-Hijleh, "Assessment of human productivity drivers for construction labor through importance rating and risk mapping," Sustain., vol. 12, no. 20, pp.

[4] M. T. Shafiq and M. Afzal, "Potential of virtual design construction technologies to improve job-site safety in gulf corporation council," Sustain., vol. 12, no. 9, 2020, doi: $10.3390 /$ su12093826.

[5] HSA, "Workplace Safety and Health Management: Practical guidelines on the implementation and maintenance of an occupational safety, health and welfare management system," Heal. Saf. Auth., pp. 1-56, 2006, [Online]. Available: https://www.hsa.ie/eng/Publications_and_Forms/Publications/Safety_and_Health_Manage ment/Workplace_Safety_and_Health_Management.pdf.

[6] J. Izudi, V. Ninsiima, and J. B. Alege, "Use of Personal Protective Equipment among Building Construction Workers in Kampala, Uganda," J. Environ. Public Health, vol. 2017, no. November 2015, 2017, doi: 10.1155/2017/7930589.

[7] A. G. Zohry, "Rural-to-Urban Labor Migration : A Study of Upper Egyptian Laborers in Cairo," p. 308, 2002.

[8] J. P. Cortés-Pérez, A. Cortés-Pérez, and P. Prieto-Muriel, "BIM-integrated management of occupational hazards in building construction and maintenance," Autom. Constr., vol. 113, no. June 2019, p. 103115, 2020, doi: 10.1016/j.autcon.2020.103115.

[9] A. Charehzehi and A. Ahankoob, "Enhancement of safety performance at construction site," no. November 2012, 2015.

[10] S. Ahmed, H. Islam, I. Hoque, and M. Hossain, "Reality check against skilled worker parameters and parameters failure effect on the construction industry for Bangladesh," Int. J. Constr. Manag., vol. 20, no. 5, pp. 480-489, 2020, doi: 10.1080/15623599.2018.1487158.

[11] J. Wong, J. Gray, and Z. Sadiqi, "Barriers to good occupational health and safety (OHS) practices by small construction firms," J. Constr. Manag., vol. XXX, no. I, pp. 55-66, 2015.

[12] M. Dagdeviren, "Health and Safety in the Construction Industry ; ' Challenges and Solutions in the Turkish Construction Industry' Health and Safety in the Construction Industry; ‘ Challenges and Solutions in the Turkish Construction Industry ' Murat Dagdeviren Submitte," no. September, 2018.

[13] V. H. P. Vitharana, G. H. M. J. S. De Silva, and S. De Silva, "Health hazards, risk and safety practices in construction sites - a review study,” Eng. J. Inst. Eng. Sri Lanka, vol. 48, no. 3, p. 35, 2015, doi: 10.4038/engineer.v48i3.6840. 
[14] A. Kazaz, S. Ulubeyli, T. Acikara, and B. Er, "Factors Affecting Labor Productivity: Perspectives of Craft Workers," Procedia Eng., vol. 164, no. June, pp. 28-34, 2016, doi: 10.1016/j.proeng.2016.11.588.

[15] В. М. За and П. Лет, "Бюллетень науки и практики / Bulletin of Science and Practice http://www.bulletennauki.com T. 5 . № 3. 2019,” vol. 85, no. 045, pp. 262-271, 2019.

[16] M. Akbar, K. K. Darkwah, A. Amin, P. Huali, O. Guoqiang, and M. Asghar, "The factors affecting labour productivity in the construction of prestressed concrete buildings in Ghana," no. April, 2021, doi: 10.20944/preprints202104.0147.v1.

[17] Z. Isik, D. Arditi, I. Dikmen, and M. T. Birgonul, "Impact of corporate strengths/weaknesses on project management competencies," Int. J. Proj. Manag., vol. 27, no. 6, pp. 629-637, 2009, doi: 10.1016/j.ijproman.2008.10.002.

[18] F. T. Edum-Fotwe and R. McCaffer, "Developing project management competency: Perspectives from the construction industry," Int. J. Proj. Manag., vol. 18, no. 2, pp. 111-124, 2000, doi: 10.1016/S0263-7863(98)90075-8.

[19] A. Soekiman, K. S. Pribadi, B. W. Soemardi, and R. D. Wirahadikusumah, "Factors relating to labor productivity affecting the project schedule performance in Indonesia," Procedia Eng., vol. 14, pp. 865-873, 2011, doi: 10.1016/j.proeng.2011.07.110.

[20] I. A. Rahman, A. H. Memon, A. Q. Memon, M. A. Shaikh, and F. Siddiqui, "Factors Affecting the Labour Productivity in Construction Projects of Pakistan," MATEC Web Conf., vol. 266, p. 05010, 2019, doi: 10.1051/matecconf/201926605010.

[21] I. Mahamid, "Contractors perspective toward factors affecting labor productivity in building construction," Eng. Constr. Archit. Manag., vol. 20, no. 4, pp. 446-460, 2013, doi: 10.1108/ECAM-08-2011-0074.

[22] Ashebir Alyew, "A Study on Factors Affecting Labour Productivity on Construction Projects in Wolaita Zone, Ethiopia,” Int. J. Eng. Res., vol. V8, no. 12, pp. 817-822, 2020, doi: $10.17577 /$ ijertv8is 120385.

[23] A. Enshassi, S. Mohamed, Z. A. Mustafa, and P. E. Mayer, "Factors affecting labour productivity in building projects in the Gaza strip," J. Civ. Eng. Manag., vol. 13, no. 4, pp. 245-254, 2007, doi: 10.1080/13923730.2007.9636444.

[24] Z. Yin and C. Caldas, "Scaffolding in industrial construction projects: current practices, issues, and potential solutions," Int. J. Constr. Manag., vol. 0, no. 0, pp. 1-10, 2020, doi: 10.1080/15623599.2020.1808562.

[25] P. K.V, V. Vasugi, V. R, and N. Bhat, "Analysis of causes of delay in Indian construction projects and mitigation measures," J. Financ. Manag. Prop. Constr., vol. 24, no. 1, pp. 58-78, 2019, doi: 10.1108/JFMPC-04-2018-0020.

[26] S. Sandbhor and R. Botre, "Applying total interpretive structural modeling to study factors affecting construction labour productivity," Australas. J. Constr. Econ. Build., vol. 14, no. 1, pp. 20-31, 2014, doi: 10.5130/ajceb.v14i1.3753.

[27] P. Pornthepkasemsant and S. Charoenpornpattana, "Identification of factors affecting 
productivity in Thailand's construction industry and proposed maturity model for improvement of the productivity," J. Eng. Des. Technol., vol. 17, no. 5, pp. 849-861, 2019, doi: 10.1108/JEDT-10-2017-0109.

[28] B. Chigara and T. Moyo, "Factors Affecting Labor Productivity on Building Projects in Zimbabwe," Int. J. Archit. Eng. Constr., vol. 3, no. 1, pp. 57-65, 2014, doi: 10.7492/ijaec.2014.005.

[29] R. Almamlook, M. Bzizi, M. Al-Kbisbeh, T. Ali, and E. Almajiri, "Factors Affecting Labor Productivity in the Construction Industry," Am. J. Environ. Sci. Eng., vol. 4, no. 2, p. 24, 2020, doi: 10.11648/j.ajese.20200402.13.

[30] B. B. Akomah, R. W. Lawson, and E. N. Jackson, "Improving Labour Productivity in Ghanaian Building Construction Projects,” Balt. J. Real Estate Econ. Constr. Manag., vol. 8, no. 1, pp. 152-169, 2020.

[31] A. J. Awad, "Construction Safety in Kingdom of Saudi Arabia," 2013, [Online]. Available: https://pdfs.semanticscholar.org/afb2/4d4131a103629865cbd347228b1791abf208.pdf.

[32] E. Abukhashabah, A. Summan, and M. Balkhyour, "Occupational accidents and injuries in construction industry in Jeddah city," Saudi J. Biol. Sci., vol. 27, no. 8, pp. 1993-1998, 2020, doi: 10.1016/j.sjbs.2020.06.033.

[33] I. A. Rahman, A. H. Memon, and A. T. A. Karim, "Significant factors causing cost overruns in large construction projects in Malaysia,” J. Appl. Sci., vol. 13, no. 2, pp. 286-293, 2013, doi: 10.3923/jas.2013.286.293.

[34] R. F. Aziz, "Ranking of delay factors in construction projects after Egyptian revolution," Alexandria Eng. J., vol. 52, no. 3, pp. 387-406, 2013, doi: 10.1016/j.aej.2013.03.002.

[35] M. Saravanan and G. Surendar, "Analysis Of Various Factors Influencing Labour Productivity In Construction Project," Int. J. Emerg. Technol. Comput. Sci. Electron., vol. 22, no. 2, pp. 179-181, 2016.

[36] F. Leccese, G. Salvadori, M. Casini, and M. Bertozzi, "Lighting of indoor work places: Risk assessment procedure," WIT Trans. Inf. Commun. Technol., vol. 44, no. January 2014, pp. 89-101, 2012, doi: 10.2495/RISK120091.

[37] K. Imriyas, S. P. Low, A. L. Teo, and S. L. Chan, "Premium-Rating Model for Workers' Compensation Insurance in Construction," J. Constr. Eng. Manag., vol. 134, no. 8, pp. 601617, 2008, doi: 10.1061/(asce)0733-9364(2008)134:8.(601)

[38] C. Ajila and A. Abiola, "Influence of Rewards on Workers Performance in an Organization," J. Soc. Sci., vol. 8, no. 1, pp. 7-12, 2004, doi: 10.1080/09718923.2004.11892397.

[39] Y. A. Istomina and J. V. Ivanchina, "Labor and Family Responsibilities: Updated Approaches in Law," vol. 498, pp. 129-134, 2020, doi: 10.2991/assehr.k.201205.023.

[40] K. Chandrasekar, "Workplace environment and its impact on organisational performance in public sector organisations,” Int. J. Enterp. Comput. Bus. Syst., vol. 1, no. 1, pp. 1-19, 2011.

[41] I. Othman, M. Kamil, R. Y. Sunindijo, M. Alnsour, and A. F. Kineber, "Critical success factors influencing construction safety program implementation in developing countries," J. 
Phys. Conf. Ser., vol. 1529, no. 4, 2020, doi: 10.1088/1742-6596/1529/4/042079.

[42] U. Produced and P. C. C. P. Manager, "Health and Safety: The Procurement of Contractors , Suppliers and Partner Organisations Policy," no. June, 2012.

[43] P. B. Setiadi, R. Ursula, R. Rismawati, and M. Setini, "Labour Productivity, Work Experience, Age and Education: The Case of Lurik Weaving Industry in Klaten, Indonesia," Webology, vol. 17, no. 2, pp. 487-502, 2020, doi: 10.14704/WEB/V17I2/WEB17047.

[44] K. A. Shamsuddin, A. K. Ismail, C. ani M. Norzaimi, and M. R. bin Ibrahim, "(PDF) Investigation the Safety, Health and Environment (SHE) Protection in Construction Area," Int. Res. J. Eng. Technol. , vol. 2, no. 6, pp. 624-636, 2015, [Online]. Available: https://www.researchgate.net/publication/282747785_Investigation_the_Safety_Health_and _Environment_SHE_Protection_in_Construction_Area.

[45] M. O. Sanni-anibire, A. S. Mahmoud, M. A. Hassanain, and B. A. Salami, "A risk assessment approach for enhancing construction safety performance," Saf. Sci., vol. 121, no. August 2019, pp. 15-29, 2020, doi: 10.1016/j.ssci.2019.08.044.

[46] C. Town and J. Thomas, "HYPERION SOLAR DEVELOPMENT 3 AND ASSOCIATED INFRASTRUCTURE NEAR KATHU , NORTHERN CAPE PROVINCE," vol. 27, no. May, 2019.

[47] A. Charehzehi and A. Ahankoob, "Enhancement Of Safety Performance At Construction Site,” Int. J. Adv. Eng. Technol., vol. 5, no. 1, pp. 303-312, 2012.

[48] L. D. Nguyen, S. O. Ogunlana, and D. T. X. Lan, “A study on project success factors in large construction projects in Vietnam," Eng. Constr. Archit. Manag., vol. 11, no. 6, pp. 404-413, 2004, doi: 10.1108/09699980410570166.

[49] Y. Chinniah, "Analysis and prevention of serious and fatal accidents related to moving parts of machinery," Saf. Sci., vol. 75, pp. 163-173, 2015, doi: 10.1016/j.ssci.2015.02.004.

[50] H. M. Al-Tabtabai, “Analyzing construction site accidents in Kuwait," Kuwait J. Sci. Eng., vol. 29, no. 2, pp. 213-238, 2002.

[51] “Iccrem 2020 538," no. 2007, pp. 538-546, 2020.

[52] B. M. Varghese et al., "Heat-related injuries in Australian workplaces: Perspectives from health and safety representatives," Saf. Sci., vol. 126, no. October 2019, p. 104651, 2020, doi: 10.1016/j.ssci.2020.104651.

[53] L. Bikitsha and C. Amoah, "Assessment of challenges and risk factors influencing the operation of emerging contractors in the Gauteng Province, South Africa," Int. J. Constr. Manag., vol. 0, no. 0, pp. 1-10, 2020, doi: 10.1080/15623599.2020.1763050.

[54] M. N. Maliha, Y. I. Abu Aisheh, B. A. Tayeh, and A. Almalki, "Safety barriers identification, classification, and ways to improve safety performance in the architecture, engineering, and construction (Aec) industry: Review study," Sustain., vol. 13, no. 6, 2021, doi: $10.3390 /$ su13063316.

[55] T. Assegaai and H. Schneider, "Factors Associated With Workplace and Interpersonal Trust in the Supervisory System of a Community Health Worker Programme in a Rural South 
African District," Int. J. Heal. Policy Manag., no. x, pp. 1-8, 2021, doi: 10.34172/ijhpm.2021.03.

[56] M. A. Smita Bhole, "Safety Problems and Injuries on Construction Site: A Review," Int. J. Eng. Tech., vol. 2, no. 4, [Online]. Available: http://www.ijetjournal.org.

[57] A. Alharahsheh and F. Nouban, "ASSESSMENT AND ANALYSIS OF SAFETY MANAGEMENT IN,” vol. 11, no. June, pp. 92-99, 2020.

[58] M. Gul and M. F. Ak, Assessment of occupational risks from human health and environmental perspectives: a new integrated approach and its application using fuzzy BWM and fuzzy MAIRCA, vol. 34, no. 8. Springer Berlin Heidelberg, 2020.

[59] R. M. Choudhry and D. Fang, "Why operatives engage in unsafe work behavior: Investigating factors on construction sites," Saf. Sci., vol. 46, no. 4, pp. 566-584, 2008, doi: 10.1016/j.ssci.2007.06.027.

[60] S. Shaikh and S. H. Panhwar, "An assessment of health \& safety measures at construction sites : A case study of Qasimabad \& Latifabad, Hyderabad,” no. May, pp. 5-8, 2020.

[61] C. M. Tam, S. X. Zeng, and Z. M. Deng, "Identifying elements of poor construction safety management in China," Saf. Sci., vol. 42, no. 7, pp. 569-586, 2004, doi: 10.1016/j.ssci.2003.09.001.

[62] W. Simukonda, P. Manu, A. M. Mahamadu, and K. Dziekonski, "Occupational safety and health management in developing countries: a study of construction companies in Malawi," Int. J. Occup. Saf. Ergon., vol. 26, no. 2, pp. 303-318, 2020, doi: 10.1080/10803548.2018.1482649.

[63] S. Durdyev, S. Mohamed, M. L. Lay, and S. Ismail, "Key factors affecting construction safety performance in developing countries: Evidence from Cambodia," Constr. Econ. Build., vol. 17, no. 4, pp. 48-65, 2017, doi: 10.5130/AJCEB.v17i4.5596.

[64] T. M. Abokhashabah, B. Jamoussi, A. Summan, and E. Abdelfattah, "A review of occupational exposure to heat stress, its health effects and controls among construction industry workers, A case of Jeddah, KSA," Int. J. Biosci., no. October, 2020, doi: 10.12692/ijb/17.1.35-45.

[65] M. Taha, S. Rafay, and A. Bukhari, "Analysis of Key Factors Affecting Labor Productivity in General Construction Projects in Pakistan Analysis of Key Factors Affecting Labor Productivity in General Construction Projects in Pakistan,” no. February 2019, 2021.

[66] M. D. Fernández, S. Quintana, N. Chavarría, and J. A. Ballesteros, "Noise exposure of workers of the construction sector," Appl. Acoust., vol. 70, no. 5, pp. 753-760, 2009, doi: 10.1016/j.apacoust.2008.07.014.

[67] S. Chi and S. Han, "Analyses of systems theory for construction accident prevention with specific reference to OSHA accident reports," Int. J. Proj. Manag., vol. 31, no. 7, pp. 10271041, 2013, doi: 10.1016/j.ijproman.2012.12.004.

[68] B. Shao, Z. Hu, Q. Liu, S. Chen, and W. He, "Fatal accident patterns of building construction activities in China," Saf. Sci., vol. 111, no. July, pp. 253-263, 2019, doi: 
10.1016/j.ssci.2018.07.019.

[69] I. Ahmad, M. A. Balkhyour, T. M. Abokhashabah, I. M. Ismail, and M. Rehan, "Workplace Safety and Health Conditions and Facilities in Small Industries in Jeddah, Saudi Arabia," J. Saf. Stud., vol. 3, no. 1, p. 37, 2017, doi: 10.5296/jss.v3i1.11104.

[70] T. H. E. P. S, “Environmental Hazards 2 (2000) 3\}9”.

[71] B. D. Lushniak, “Occupational skin diseases,” Prim. Care - Clin. Off. Pract., vol. 27, no. 4, pp. 895-915, 2000, doi: 10.1016/S0095-4543(05)70183-4.

[72] Z. Wang, S. Zaman, S. F. Rasool, Q. U. Zaman, and A. Amin, "Exploring the relationships between a toxic workplace environment, workplace stress, and project success with the moderating effect of organizational support: Empirical evidence from Pakistan," Risk Manag. Healthc. Policy, vol. 13, pp. 1055-1067, 2020, doi: 10.2147/RMHP.S256155. 